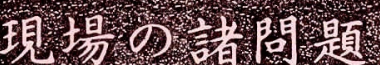

\section{原子吸光分析用黒鉛のパイロリティックグ ラファイト化}

黑鉛炉原子吸光分析法は微少試料を高感度で分析する 方法として，普及されてきているが，応用に際して問題 が少くない，黒鉛を試料原子化の発熱体として使用して いるので，分析試料の黒鉛への吸着や，化合物の生成， 黒鉛自体の消耗などが，トラブルの一因になることが考 えられている.これに対処するために，黒鉛発熱体の材 質や構造, 測定時の操作条件などについて，種々の試み がなされている. その一つとして，発熱体黑鉛を炭化水 素を含む雾囲気で加熱し，その過程で得られる遊離炭素 成分を黑鉛表面に被覆する，いわわるパイロリティック グラファイトコーティング処理（以下 P. G. 処理と略す） による効果については，すでに研究例がある ${ }^{1-3)}$. 発熱 体の長寿命化, 若干の元素に対する感度増大効果などが 指摘されている、筆者も P.G. 処理黒鉛炉を日常の分 析に応用するために検討を進めてきたので，ここでその 概要について紹介する.

\section{P. G. 処理方法}

ここでは原子吸光分析装置として日立 308 型を，黒鉛 炉としてパーキンエルマHGA2000 型を使用した. P.G. 処理は，いわゆる直接加熱法を用いたまず黒鉆管（長 さ $53 \mathrm{~mm}$, 内径 $8.5 \mathrm{~mm}$, 外径 $10.5 \mathrm{~mm}$ : パーキンェ ルマ製) 党炉にセットしてから，ガス混合系（三方コッ クと 2 組のガスンース，流量計，流量調節弁を組合せた） より，含炭化水素ガスを黒鉛炉内に送気し，黑鉛管を通 電加熱させることによって行なった（処理温度および 原子吸光測定温度の設定は装置の温度目盛に従った).な 括 P. G. 処理は黒鉛管の内面括よび外面について行な った．寿命への効果を考えると，仙面を処理するのが有 利と思われる。

P. G. 処理のッースとして，ここではィタンとアルゴ ンの混合体を使用した．炭化水素の濃度は $1 \%$ 程度でも 原子吸光強度への効果が認妨らるが，低濃度では安定 化に長時間を要する. 実際の処理は, メタン濃度 $5 \sim 10$ $\%$ ，送気量は0.5〜11/min が適当であった.な持ガス混 合の手間をはぶくために，市販のメタン，アルゴン混合 ガス (ガスフロータイプ P.C. カウンタ用 $\mathrm{PR}$ ガス ; Ar: $\left.\mathrm{CH}_{4}=9: 1\right)$ を使用するのも便利である.

P. G. 処理に際し処理温度は, 得られる黒鉛の密度な
ぞ諸性質への影響が大きい. P. G. 処理のための炭化水 素の熱分解温度は $1200 \sim 2500^{\circ} \mathrm{C}$ と幅が広いが，原子吸 光の感度の面から考察すると, 最適温度は $2200^{\circ} \mathrm{C}$ 付近 と思えれる. 処理温度 $1900^{\circ} \mathrm{C}$ 以上で吸光度は急激に増 大するが, $2200^{\circ} \mathrm{C}$ 以上では飽和の傾向が認められた.

P. G. 処理が十分に達成されるまでの所要時間は，上 記の諸条件によって違ってくるが，例えばメタン浱度 $5 \sim 10 \%$, 处理温度 $2200^{\circ} \mathrm{C}$ の処理過程に批いて, バナ ジウムの原子吸光強度の增加は， $1 \sim 2$ 分の間で急激に 行われ，先の後間もなく頭打ちとなった，乙かし寿命の 点からはコーティングはさらに或る程度厚くする方が良 さそうである。この実験で滦湾満足と思われる処理時間 6 分飞执いて，P. G. 折出量は扰上そ $100 \mathrm{mg}$ 程度で㘯 り, 黑鉛管中央部での被覆の厚さは数+ $\mu$ と思われる. 京た電気抵抗值は P. G. 処理前に比較して約 $10 \%$ 低下 することが判った. (ややバラッキがあるが, $223 \times 10^{-2}$ $\Omega \mathrm{cm}$ である.)

この P. G. 処理後の電気抵抗の变化によって処理管 の通電侍の温度が，未処理の管とは異ってくることが考 えられる. 光高温計によって測定の結果, 通電初期では 未処理管と同じ設定温度 $2500^{\circ} \mathrm{C}$ 亿拈いて, 約 $50^{\circ} \mathrm{C}$ 低 い温度が測定されたが，通電10秒後では殆んぞ同じ温度 に到達するようにみえる。(両者の emissivity の補正は 行なっていない）しかし黒鉛炉法では, 炉の温度の上 昇過程で測定が始まるので, 箃密には原子化温度に違い の西ることを，考虑すべきかと思われる．P. G. 処理層 の厚さが, 過大になるとこの問題はさらに助長されるで あろう.

\section{P. G. 処理効果}

P. G. 処理による原子吸光の感度向上への効果は, 約

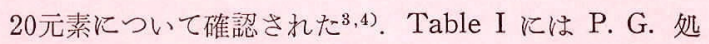
理前後の各元素の検出 限界 $(\mathrm{S} / \mathrm{N}=2$ 飞対応寸る吸光度 を示す絶刘量）を示した. 最高 6 倍程度の増感効果が認 められる。な抗ここでは測定値として，信号のピークハ イトを用いた。

参考までに，既発表の各元素への増感効果の状況は, マンガン、ニッケル，銀，金，べリリウム，リチウム， レニウム，アンチモンなどに対しては，P. G. 処理が有 効とされる1)が，錫，アルミニウムでは，効果は認めら れない(3)ようである。しかし, これらの評価は, 実験者 によって必ずしも一致していない，実験の方法や装置な どの違いが原因として考光られるが，倹討の余地が残さ れている.

P. G. 処理管の寿命は明らかに改善され，とくに高温 
Table I P. G. 処理前後の各元素の検出限界3.4).

\begin{tabular}{c|c|cl|r}
\hline \hline Element & $\begin{array}{c}\text { Wave- } \\
\text { length } \\
\text { (nm) }\end{array}$ & $\begin{array}{c}\text { Detection limit } \\
\text { (ng) }\end{array}$ & $\begin{array}{c}\text { Enhance- } \\
\text { ment }\end{array}$ \\
\hline $\mathrm{Uncoated}$ P. G. coated & factor \\
\hline $\mathrm{Ba}$ & 553.6 & 0.1 & 0.02 & 5.0 \\
$\mathrm{Ca}$ & 442.7 & 0.006 & 0.002 & 3.0 \\
$\mathrm{Cu}$ & 324.7 & 0.025 & 0.010 & 2.5 \\
$\mathrm{Er}$ & 400.8 & 1.4 & 0.5 & 2.7 \\
$\mathrm{Eu}$ & 459.4 & 0.11 & 0.04 & 2.7 \\
$\mathrm{Fe}$ & 248.3 & 0.032 & 0.018 & 1.8 \\
$\mathrm{Gd}$ & 407.8 & 24. & 4. & 6.0 \\
$\mathrm{Ho}$ & 410.4 & 0.5 & 0.2 & 2.5 \\
$\mathrm{La}$ & 550.1 & 25. & 4. & 6.2 \\
$\mathrm{Mo}$ & 313.3 & 0.10 & 0.025 & 4.0 \\
$\mathrm{~Pb}$ & 217.0 & 0.04 & 0.024 & 1.6 \\
$\mathrm{Pr}$ & 495.1 & 12. & 4. & 3.0 \\
$\mathrm{Sm}$ & 429.7 & 2.4 & 0.4 & 6.0 \\
$\mathrm{Sr}$ & 460.7 & 0.05 & 0.008 & 6.2 \\
$\mathrm{~Tb}$ & 432.7 & 18. & 5. & 3.6 \\
$\mathrm{Ti}$ & 365.3 & 0.80 & 0.12 & 6.6 \\
$\mathrm{~V}$ & 318.4 & 0.30 & 0.05 & 6.0 \\
$\mathrm{Y}$ & 410.2 & 2.1 & 0.6 & 3.5 \\
$\mathrm{Yb}$ & 398.8 & 0.03 & 0.01 & 3.0 \\
\hline & & & & \\
\hline
\end{tabular}

度で測定を行なら元素への適用において有効であった。 バナジゥム, チタニウム, 希上類元素などのように, 高 い原子化温度で，乙かる比較的長い原子化時間を要する 元素を測定する場合に执いては, 黒鉛管の消耗が無視で きない，黒鉛管の電気抵抗の変化の状況は，その寿命を 予測する手がかりとなり得る・例党ば原子化操作を $2700^{\circ}$ C15秒でくり返し測定する場合, 未処理管の50回測定後 に执いては，抵抗值が約 $15 \%$ 増大する (寿命末期となる)
が, P. G. 処理管（ハタン濃度 $10 \%$, 処理 $2200^{\circ} \mathrm{C} 6$ 分) では 120 回の測定後に扣いて約 $8 \%$ 增大する程度であっ た.

P. G. 処理管では，一旦得られた増感性は長時間にわ たり維持され,測定の再現性も初期を除き良好であった。

例えばバナジゥムについて，P. G. 処理後 (バナジウ 厶の感度は約 6 倍に増大している) $, 2700^{\circ} \mathrm{C}, 15$ 秒で 120 回の測定をくり返し行なった後の原子吸光強度の低下 は, 約10\%であった.

また測定の再現性は, P. G. 処理直後から120回目まで の測定に䊉いて，10回ごとの変動率を求めてみると，初 回から10回目末でのそれは10\%程度であったが, 11回目 以後120回目までの測定では，注ぼ 2 〜\%を維持して いる.つまり，初期に扣いて安定を欠く時期があるが， やがてかなり長い安定期に入ることがいえる.この初期 飞猢丕安定な状況は, Manning ら ${ }^{1)}$ とっても示 されているが、ここでとりあげたバナジウム,バリウム， ストロンチウム，鉄など多くの元素の測定に批いても認 められた. P. G. 処理後は, 測定の状態で数回の空焼き を行なってから，本測定に移るのがよい。

終りと，討論いただいた日立製作所那坷工場内野氏㧍 よび原田氏に感謝いたします。

\section{文献}

1) D. C. Manning, R. E. Ediger: At. Absorp. Newsl. 15, 42 (1976).

2) R. E. Sturgeon, C. L. Chakrabarti: Anal. Chem. 49, 90 (1977).

3) 久我, 辻井：分析化学 27,441 (1978).

4) 久我：未発表.

（日立中研 久我和夫，辻井完次） 